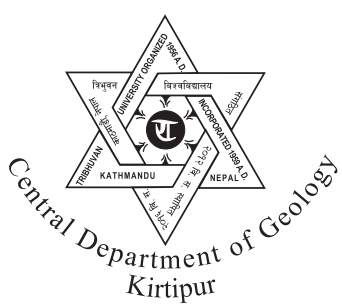

\title{
Process of cement production in Nepal
}

\author{
*Paresh Raj Pandey ${ }^{1}$ and Narayan Banskota ${ }^{2}$ \\ ${ }^{1}$ Central Department of Geology, Tribhuvan University, Kirtipur, Kathmandu, Nepal \\ ${ }^{2}$ CG Cement, Sanepa, Kathmandu
}

\begin{abstract}
This paper describes general process of cement production from exploration of limestone deposit to production of clinker and finally cement. Exploration of limestone comprises area selection, target definition, reserve calculation, resource evaluation and reserve definition. After exploration, mining is taken up. Quarried limestone is stockpiled and then is blended with other raw material like clay/shale, silica, iron ore in required proportion. The blended material is then heated at high temperature upto $1400-1450{ }^{\circ} \mathrm{C}$ in a kiln to produce clinker. The clinker is grinned along with $3-5 \%$ gypsum to produce cement.
\end{abstract}

\section{INTRODUCTION}

Ordinary portland ceement is produced by grinding cement clinker along with gypsum (about $3-5 \%$ ) to specified fineness depending on the requirements of the cement consumers. Cement clinker is produced on large scale by heating finely pulverised calcareous and argillaceous materials at $1400{ }^{\circ} \mathrm{C}$ in rotary kilns. The materials obtained from the earth are proportioned to obtain a suitable ratio of lime, silica, alumina and iron present in the mixture. As the raw materials are obtained directly from limestone and clay mines, minor constituents like magnesia, sodium, potassium, sulphur, chlorine compounds, etc. may also be present in the raw materials upto limited extent that do not harm proccessing and cement product.

Limestone is a main raw material of cement and is composed mainly of calcium carbonate. Limestone required for cement production is estimated about $85 \%$ (Alsop 2007). Various studies were conducted

*Corresponding author:

E-mail address: pareshpandey@gmail.com with a view to understand the potential limestone deposits. Khatri (1977) reported the potential deposit of limestone between Sindali and Keyureni (quarry site of Udaypur Cement Factory). Jha (1978) carried out the exploration work in the northwestern part of the Sindali Limestone Deposit. In 1978 Japan International Cooperation Agency (JICA) performed chemical analysis during the feasibility study of the Udayapur Limestone. A research team in 1993 worked in detail around the Sindali area and estimated the reserve of about 73.5 million tons.Different varieties of limestone are found in Nepalese territory. Out of total $147,181 \mathrm{sq} . \mathrm{km}$. of nation's area, limestone occupies about 7000 sq. km. About 985 million tons of limestone reserves of different categories including 139 million tons of proved reserve have been reported by DMG (2004). Nepal's annual demend of cement is estimated at 2,940, 000 MT (personal communication with Department of Custom 2007; DMG 2008). The production capacity installed in two state-owned mine-based industries and about 20 private clinker-based factories are above 961,000 MT, and the consumption of cement is about 102 


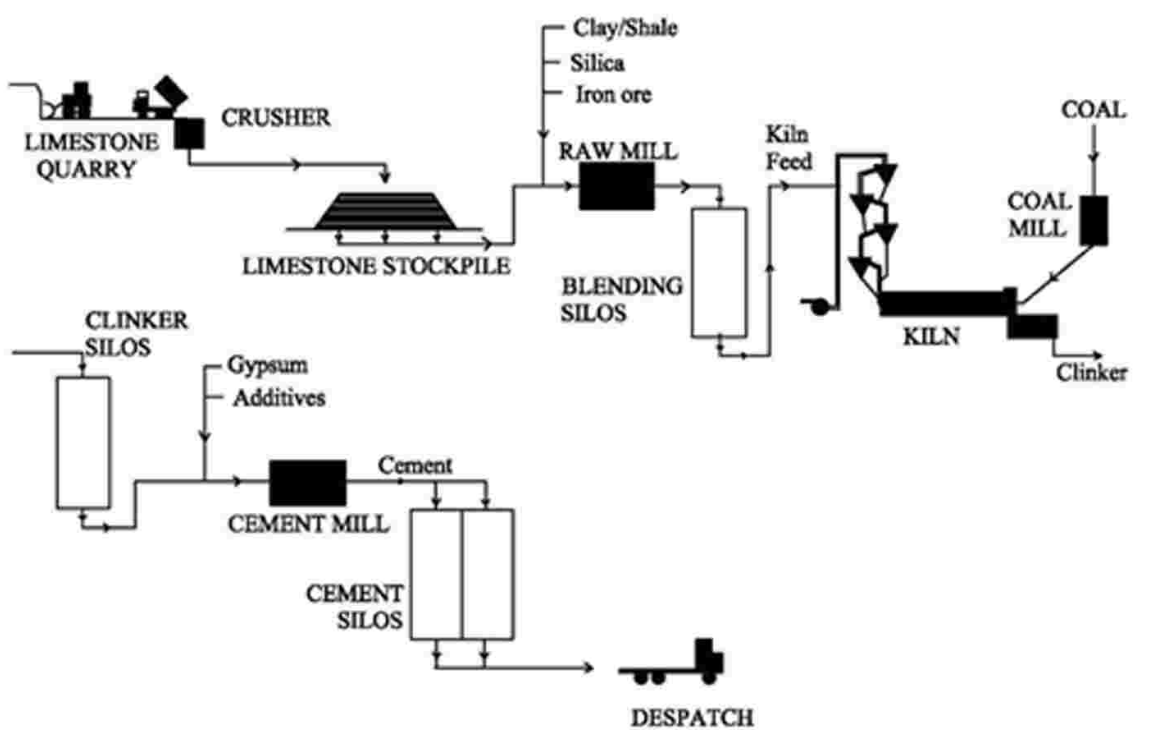

Fig. 1 Schematic diagram of cement manufacturing process

kg/head/year (DMG 1993; DMG 2004; DMG 2008). The domestic industries are fulfilling only about $35 \%$ of demand (DMG 2008). Comparing the demand with a supply trend, there is still space for some additional industries in this sector.

The unit operations involved in cement manufacturing process (Fig. 1) include: (1) exploration, (2) mining and preparation of raw material for kiln feed, (3) pyroprocessing of kiln feed in the presence of combustion gas/flame generated from combustion of publverised coal, mineral oil or natural gas, and (4) grinding of cement clinker along with gypsum for production of portland cement.

\section{EXPLORATION OF LIMESTONE}

Exploration consists of process of finding limestone deposit to mine, and is much more intensive, organised and professional. Exploration concerns and provides answers to the problems of the site. The major concerns during exploration are area selection, target definition, reserve estimation, resource evaluation and reserve definition (Kreiter 1966).

\section{Area selection}

Area selection is an important step that assists not only in identifying the most prospective area in a geological region for limestone deposits, but in finding them easily, cheaply and quickly. Area selection is based on knowledge of geological setting via the study of geological maps. The role of infrastructure may also be crucial. In the context of Nepal, carbonate strata of the Lesser and Tethys Himalayas are important geological regions for exploring the limestone deposits (Fig. 2). Annapurna Quarries, Kakurthakur Mines of Maruti Cement and Sindhali Mine of Udayapur Cement Industries are of the Jhiku Carbonate Bed of the Benighat Slate. The mine of Dynasty Industries is a part of the Dhading Dolomite. The ultimate result of an area selection process is the notification of exploration licenses, known as tenements.

\section{Target definition}

The target definition involves investigation of geology via geological mapping, sampling, testing of samples and drilling.

\section{Geological mapping}

Geological mapping is made through the compass traverse along rivers, rivulets, trails, road section and ridge. Regional geological mapping is carried out 


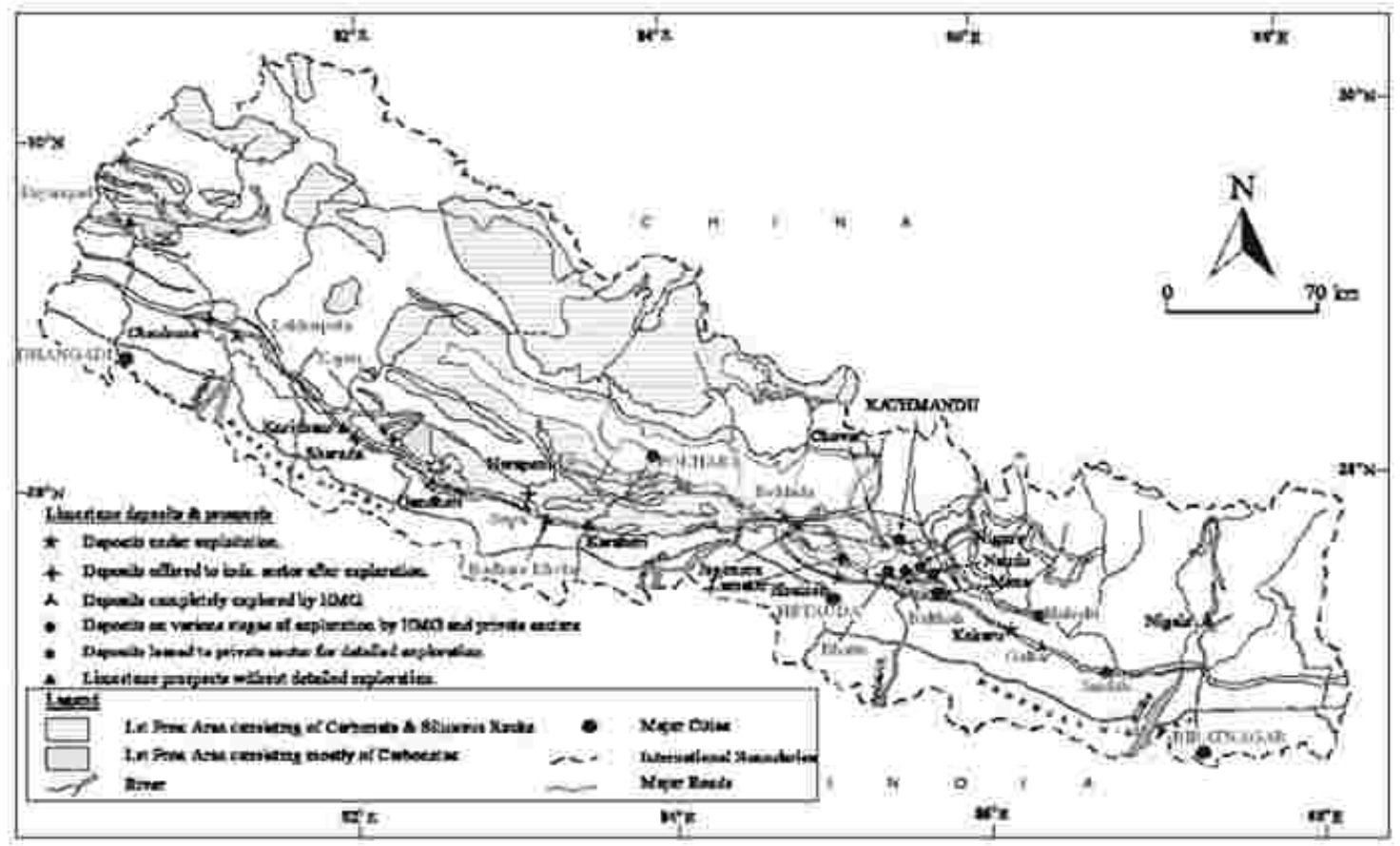

Fig. 2 Limestone distribution in Nepal (Shrestha 2001)

using 1:25,000 to $1: 10,000$ scale topographic maps. Topo-geological survey around the deposit is made in 1:1000 to $1: 2000$ scale map using Theodolite survey. Topo-geological map is generally used for reserve calculation and preparing mine plan layout.

\section{Sampling}

Samples are collected from surface or subsurface through drilling. Sampling is essential to evaluate the deposit at every stage of exploration. Three kinds of sampling; grab, chip and channel are commonly done in practice. Grab sampling is done randomly and is not intended to represent the deposit, but is assayed to determine chemical elements present in the rock. Generally, wide spacing (20-30 m) perpendicular to bedding plane is considered during the sampling.

Chip sampling is made at regular intervals of 2-5 $\mathrm{m}$ perpendicular to the bedding plane (Fig. 3). By chip sampling more detail chemical information of the deposit can be obtained. Channel sampling is reliable and is the most common method of sampling. The channels (length $=2 \mathrm{~m}$, width $=0.6 \mathrm{~m}$, depth $=$ $0.4 \mathrm{~m}$ ) are cut perpendicular to the bedding plane

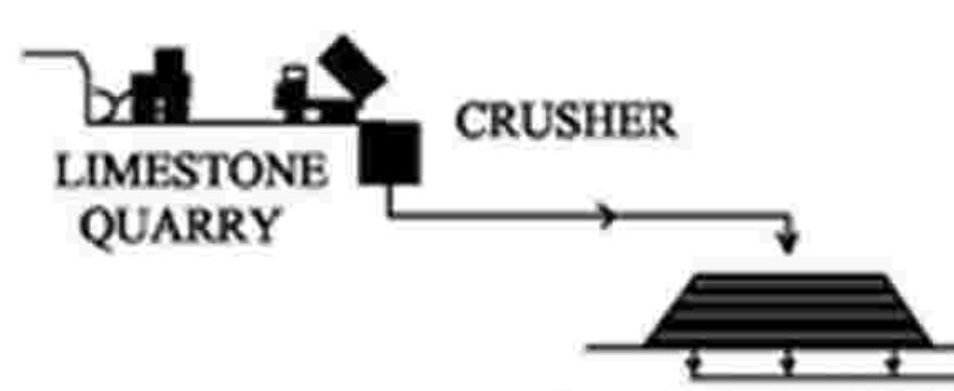

LIMESTONE STOCK

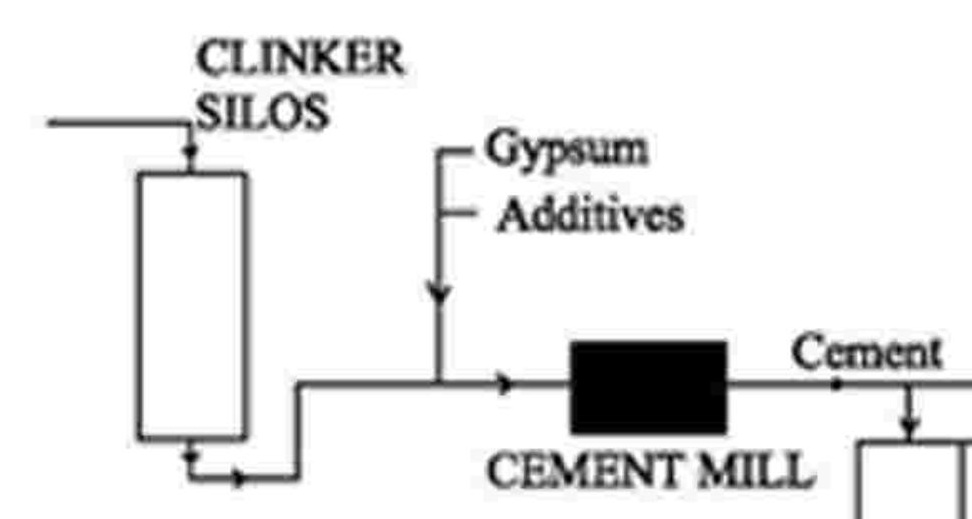




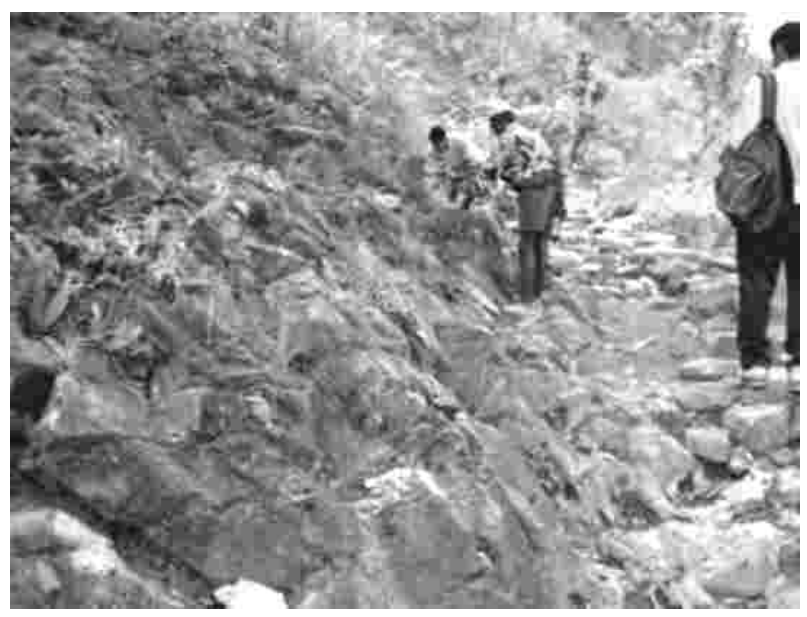

Fig. 3 chip sampling done perpendicular to bedding plane in Limestone deposit

the chemical analysis, oxides of various chemical are determined in weight percentages. During the total analysis, loss of ignition, silica, alumina, ferric oxide, calcium oxide, and magnesia contents are obtained. The result is compared with available grading system urrence in a new area.

gives only the two re, 3D view of deposit tary drilling method is g, obtaining recovery a main activities linked can be correlated with ich would help in of the bed and proving

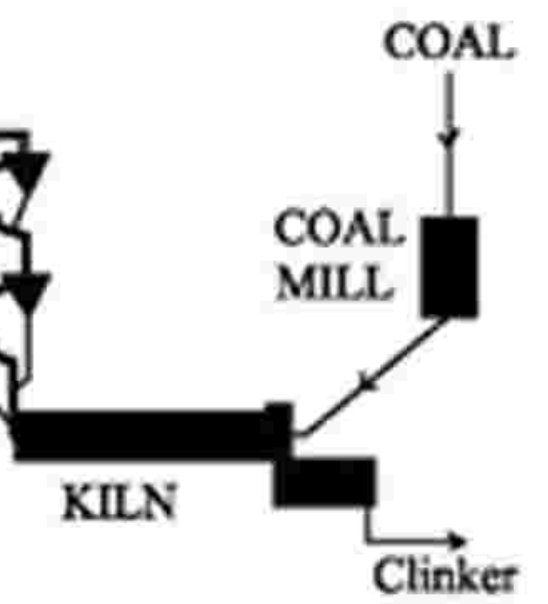

amples is prepared and , structure and visual h microscopic study. of calcite can also be ctivity of a raw meal ical composition, but on and size of crystals. fineness of constituent ivity of the raw meal grain size of various taining appropriate and Grindability

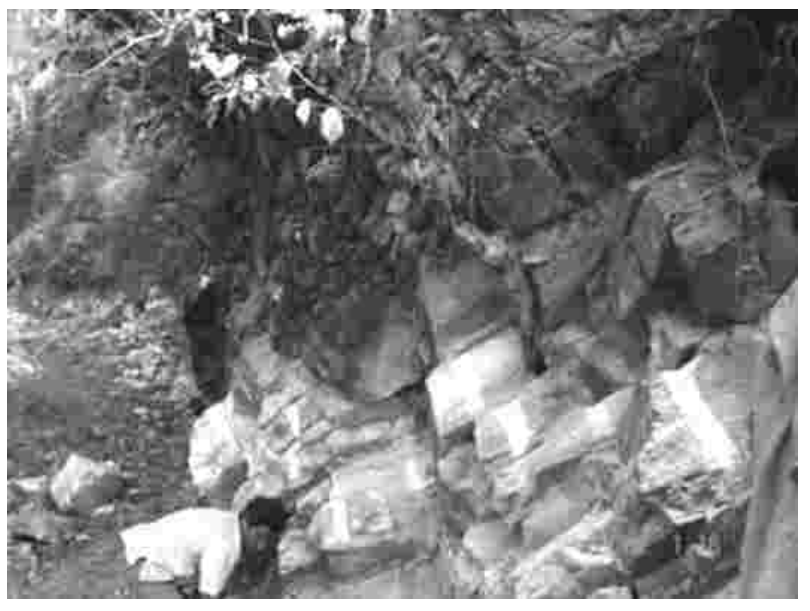

Fig. 4 Channel cut perpendicular to bedding plane in Khortar Khola Limestone deposit

characteristics of raw meal have the most pronounced effect on clinker quality.

\section{Estimation of reserve of limestone}

The estimation of reserves is an ultimate goal of a certain stage of exploration to determine quantity and quality of deposits. Ascertaining the spatial distribution of grade in deposit as a whole, and in its separate blocks and provisional determination of economic importance of the estimated reserves are also objective of reserve estimation.

In the preliminary stage, regional geological study and reserve estimation of the limestone deposit is done in 1:25000 scale topo-geological maps using the grab samples from various outcrops. From this sampling and calculation only possible reserve is estimated. In the detail stage topo-geological mapping on scale 1:1000 is done, and different chip and channel samples in regular interval are cut in deposit. From this detailed study probable and possible reserves of cement grade limestone are calculated. From drilling data only the reserve calculated is proved.

Reserve estimation are placed under three categorie:

Proved (A): The estimation is based on the sufficient data such that, it will not vary much from the actual tonnage and grade when mined.

Probable(B): Probable reserves are known as indicated reserves which carry a lesser degree of 


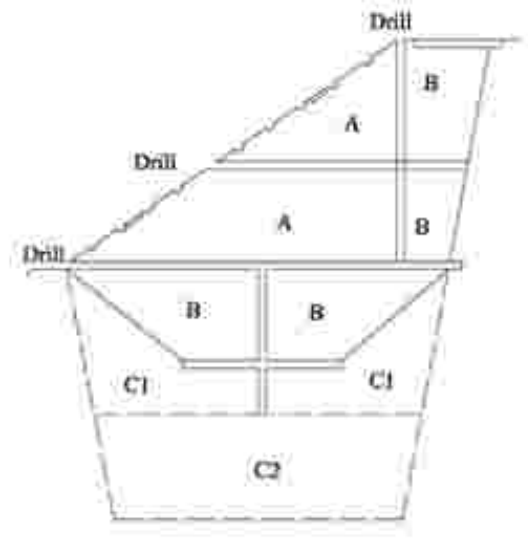

Fig. 5 Schematic classification of the reserves (Kreiter 1969)

assurance and are based on a limited data of sampling and core logging.

Possible $(\mathrm{C} 1+\mathrm{C} 2)$ : The reserve estimation when done from extrapolation of sampling data to areas where there is no data of sampling available is termed possible reserves (inferred reserves).

The reserves of deposit ' $Q$ ' in terms of tonnage can be obtained by multiplying the volume of ore body ' $\mathrm{V}$ ' or the volume of the block of the deposit " $\mathrm{V}$ ' with the tonnage factor ' $\mathrm{T}$ '.

$$
\mathrm{Q}=\mathrm{V} \times \mathrm{T}
$$

Total reserve $\mathrm{Q}=(\mathrm{V} \times \mathrm{T})$

Where $\mathrm{V}=\mathrm{St}, \mathrm{S}=$ cross area, $\mathrm{m}^{2}, \mathrm{t}=$ strike length, $\mathrm{m}, \mathrm{T}=$ Tonnage factor (the total volume in cubic meters multiplied by the specific gravity of the minerals gives directly the tonnage in metric tones. And this specific gravity here is called the tonnage factor).

The accuracy of the reserve calculation depends upon the extent to which detail works are carried out. Dividing the ore body into different blocks with respect to the sampling locations and computing the tonnage of each block separately can give the desired accuracy.

Vertical section method is used for most of the steeply dipping deposits, and for the nonmetallic and less precious minerals like limestone. In this method different cross sections are prepared across the strike of deposit with respect to the sampling point and then the cross sectional area of the deposit with desired grade is calculated and then multiplied with the strike length of the area that comes into the influence of the sampling point.

Following norms and assumption have been considered for mineable reserve and stripping ratio:

1. The influence length is the summation of half the length in between the section lines on either side of the section line.

2. The minimum mineable level of excavation varies in different sections, taking care of economic excavation of limestone up to that level.

3. Depending upon the existing natural slope, lithology and mining condition the ultimate pit slope is kept about $70^{\circ}$.

4. The specific gravity of limestone is taken as 2.6.

5. Sectional Area of limestone is found out from topo-geological mapping.

6. Recovery Factor: The recovery factor taken for this deposit is 0.8 .

\section{Resource evaluation}

Resource evaluation is undertaken to quantify the grade and tonnage of a limestone occurrence. This is achieved primarily by drilling to sample the prospective horizon or strata where the limestone of interest occurs.

The ultimate aim is to generate a density of drilling sufficient to satisfy the economic and statutory standards of an ore resource. Depending on the financial situation and size of the deposit and the structure of the company, the level of detail required to generate this resource and stage at which extraction can commence varies; for small partnerships and private non-corporate enterprises a very low level of detail is required whereas for corporations which require (loans) to build intensive extraction, the rigor necessary in resource estimation is far greater. For large cash rich companies working on small ore bodies, they may work only to a level necessary to satisfy their internal before extraction commences.

\subsection{Reserve definition}


Reserve definition is undertaken to convert limestone resource into prove reserve, which is an economic. The process is similar to resource evaluation, except more intensive and technical, aimed at statistically quantifying the grade continuity and mass of deposit. Reserve calculation of deposit is done using vertical section method.

Reserve definition also takes into account the milling and extractability characteristics of the ore, and generates bulk samples for, involving crushability, and other parameters.

Reserve definition includes assessment and studies of the rocks within and surrounding the deposit to determine the potential instabilities of proposed or methods. This process may involve drilling diamond core samples to derive information on weaknesses within the rock mass such as faults, foliations, joints and shearing.

At the end of this process, a feasibility report is published, and deposit may be either deemed uneconomic or economic.

\section{MINING OF LIMESTONE}

Mining plans are developed according to geology of the materials. If limestone is not homogeneous, it may be necessary to blend rock from different areas in order to maximize recovery and it may also be necessary to mine selectively in order to avoid low grade materials or problem. Major quantity of limestone is obtained from the captive limestone mines after deposit is proved qualitatively and quantitatively. Mining and hauling are commonly monitored by

-Stripping ratio: tons waste removed/tons used rock
-Blasting: grammes explosive/tons
-Loading: tons/hours of equipment and loader availability
-Hauling: tons/hours per truck and truck availability

Currently, cement industries of Nepal are obtaining the limestone excavated by using Opencast mining technology as by Hateuda Cement Industry and Udayapur Cement Industry as well other new quarry sites being developed.

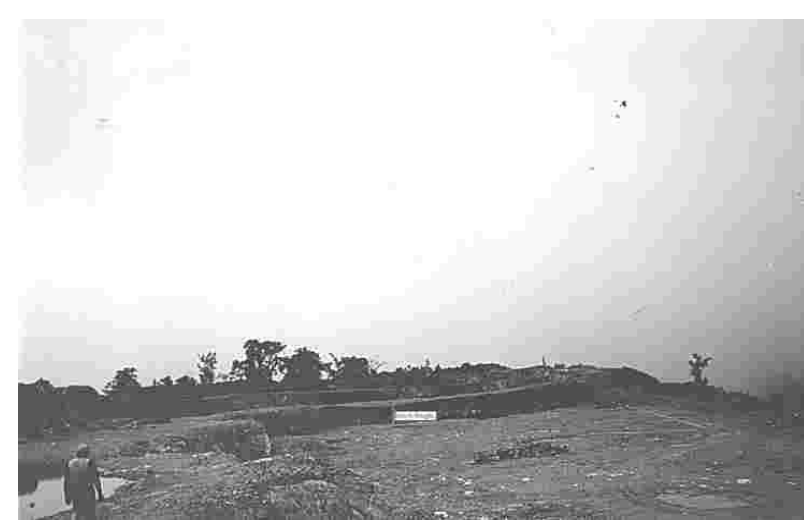

Fig. 6 Bench developed at Mine site of Udayapur Cement Industries

The mining is carried out by benching method from top to bottom (Fig. 6). The mine face and ultimate pit slope depend on slope stability of deposit area and follow the contour mining. The breaking of limestone from the quarry face is done by drilling either by Wagon drill or jack hammer drill and blasting and or in combination with the rock breaker machine. The conventional explosive used for limestone quarry is ANFO (ammounium nitrate activated with Ca 5\% of fuel oil). Usages average about $200 \mathrm{~g} / \mathrm{t}$ with considerable variation.

The blasted material are excavated by using hydraulic excavators and manual lab ours. Dozers are utilized for collection of broken limestone and leveling of the bench floor. Loading is done by power shovel and transportation by dumpers. Secondary breaking of large pieces of the limestone is done either by rock breaker machine or by holes using jack hammer and blasting.

\section{Crushing of limestone}

The boulders to small fragments are produced by drilling and blasting methods. Limestones produced are then crushed in suitable type of crushers. In some mines the crushers are installed at mine site and crushed limestone is transported to plant stack pile with the help of Belt conveyor/Ropeway.

\section{PRODUCTION OF LIMESTONE}

\section{Raw mix design}

Cement mixes vary from "cement rock", a single component which, as mined, contains appropriate proportions of all the required minerals, to four or 
Table 2 Proportion of raw materials

\begin{tabular}{ll}
\hline Material & Percent \\
\hline Limestone $(\mathrm{CaO})$ & $85 \%$ \\
Clay $\left(\mathrm{SiO}_{2}, \mathrm{Al}_{2} \mathrm{O}_{3} \& \mathrm{Fe}_{2} \mathrm{O}_{3}\right)$ & $13 \%$ \\
Additives $\left(\mathrm{SiO}_{2}, \mathrm{Al}_{2} \mathrm{O}_{3}\right.$ or $\left.\mathrm{Fe}_{2} \mathrm{O}_{3}\right)$ & $<1 \%$ each \\
\hline
\end{tabular}

five component mixes comprising one or two grades of limestone, shale, and one or more additives to augment $\mathrm{SiO}_{2}, \mathrm{Al}_{2} \mathrm{O}_{3}$ or $\mathrm{Fe}_{2} \mathrm{O}_{3}$ levels. Kiln feed typically contains $78 \quad 80 \% \mathrm{CaCO}_{3}$ so that limestone can only fall close to this level to the extent that it also contains the other ingredients. It is essential to have sufficient flux ( $\mathrm{Al}, \mathrm{Fe}, \mathrm{Mg}, \mathrm{F}$ ) to promote fusion in the kiln, but $\mathrm{MgO}$ should not exceed $6 \%$ or cement may be expansive. Excess alkalis (N, Ka) affect both kiln operation (build-up) and product quality (alkali aggregate reactivity). Excess $\mathrm{S}$ causes kiln build-ups and limits the addition of gypsum which may result in setting problems. The stoichiometric ratio of alkalis to sulfur is normally kept between $0.8-1.2$. Excess $\mathrm{Cl}(>0.015 \%)$ in the kiln feed causes serious buildup problems for preheater operation.

Materials, as mined, therefore, are typically proportioned as shown in Table 2.

Clinkerization factor is assumed to be 1.4 so, cement plants are located near to limestone deposits while clay is sufficiently ubiquitous for most plants to mine.

\section{Grinding of raw materials}

The pre-blended limestone from stack pile is transported to raw mill hoppers. More than one hoppers are used for proportioning of raw mix incase the limestone is obtained from more than one sources or sweetener or additive materials are required to be mixed with captive mines limestone. Presently Raw mill hoppers are provided with continuous weighing machines known as weigh feeders in order to produce a suitable raw meal proportioned appropriately for production of desired good quality of cement clinker.

\section{Homogenization}

The raw meal ground in the raw mill is thoroughly blended The moisture content of raw meal powder is less than $1 \%$. The properly blended raw meal is now ready for burning the same to produce cement clinker in cement rotary kiln.

\section{Burning and cooling}

The modern burning (pyroprocessing) system comprises of three important sections namely preheating and precalcining, clinkerisation and cooling. The preheating section is $90-100$ meters tall and comprises of battery of cyclones arranged one over the other in series. Precalcining of raw meal is carried out in a separate vessel vertically held and placed in between preheating and clinkerisation section. The clinkerisation reaction is carried out in a rotary kiln. The kiln is inclined at an angle of about $3-5^{\circ}$ from horizontal from preheating to the cooling end. The kilns are mounted on tyres and rotated at a speed of 2.5-4 rpm.

The combustion gases generated from burning of purlverized coal in clinkerisation zone of the kiln flows from burning zone towards the inlet of fan after passing through Kiln Precalciner-Preheater circuit. The high temperature combustion gas transfer its heat to the finally derived raw meal and falls towards the bottom end of preheater after passing through all

Table 3 Reactions of raw material in successive temperature

\begin{tabular}{ll}
\hline Temperature Process \\
\hline $100^{\circ} \mathrm{C}$ & $\begin{array}{l}\text { Evaporation of free water } \\
>500^{\circ} \mathrm{C}\end{array}$ \\
$>900^{\circ} \mathrm{C}$ & $\begin{array}{l}\mathrm{CaCO}_{3}>\quad \mathrm{CaO}+\mathrm{CO}_{2} \quad \text { (this reaction is called } \\
\text { calcinations reaction) }\end{array}$ \\
$>900^{\circ} \mathrm{C}$ & $\begin{array}{l}\text { Reactions between } \mathrm{CaO} \text { and } \mathrm{Al}_{2} \mathrm{O}_{3}, \mathrm{Fe}_{2} \mathrm{O}_{3} \text { and } \mathrm{SiO}_{2} \\
>1200^{\circ} \mathrm{C}\end{array}$ \\
$>1280{ }^{\circ} \mathrm{C}$ & Fiquid formation \\
\hline
\end{tabular}


stages of cyclones under the influence of hot gases flowing in the circuit. The moisture and other volatile contents present are completely driven away. The burning zone in rotary kiln receives complete decarbonated material, the part of which is transformed into liquid after achieving appropriate melting temperature of some of the raw meal components and powdery form of raw meal gets converted into nodulized clinker form. The final clinkerisation of raw meal is achieved between the temperature range of $1250-1450^{\circ} \mathrm{C}$ depending upon the raw meal characteristics. The high temperature clinker nodules varying in size then fall out of the kiln and enter the cooler (Table 3, Lea 1968).

\section{Cement grinding and dispatch}

In order to achieve the objectives of energy conservation, the clinker produced in rotary kiln cooled in cooler is usually stored for few days before it is ground in cement grinding mills along with appropriate quantity of gypsum and other additive materials for production of finely pulverized cement with desired fineness.

Depending upon the market requirements the cement is loaded in bulk but in Nepal generally packed in $50 \mathrm{KG}$ bags with the help of conventional rotary packs or electronic packs, loaded on to trucks and finally dispatched to the required destinations.

\section{CONCLUSION}

1. Nepal is rich in non-metallic resources especially limestone deposits which has high potential of cement production. Presently, there is enough gaps in supply and demand so there is high potentially to invest in cement industries.

2. Exploration starts from area selection to reserve definition. Only after detail exploration of limestone deposit i.e. proved deposit is ready to mine.

3. Limestone $(\mathrm{CaO})-85 \%$, clay $\left(\mathrm{SiO}_{2}, \mathrm{Al}_{2} \mathrm{O}_{3}\right.$ or $\left.\mathrm{Fe}_{2} \mathrm{O}_{3}\right)-13 \%$ other additive $\left(\mathrm{SiO}_{2}, \mathrm{Al}_{2} \mathrm{O}_{3}\right.$ or $\mathrm{Fe}_{2} \mathrm{O}_{3}$
) $<1 \%$ is typical proportion of raw mix design. And $\mathrm{MgO}$ should not exceed $6 \%$ at final composition from raw. These all raw materials are blended in required proportion and heated at high temperature upto $1400{ }^{\circ} \mathrm{C}-1450{ }^{\circ} \mathrm{C}$ in kiln to produce clinker. Cement is produced by grinding clinker with gypsum (3-5\%).

\section{REFERENCES}

Alsop, P.A., 2007. The cement plant operations handbook. Fifth edition, Tradership Publication Ltd., 276p.

Banskota, N., 2007, Planning and Design of Khortar Khola Limestone Mine, Unpublished M. Sc. Dissertation submitted to the Central Department of Geology, Tribhuvan University, 95p.

Boky, B., 1967, Mining, Mir Publisher, pp 538-581.

DMG, 1993, Atlas of mineral Resources of the ESCP region, pp. 57

DMG, 2004, Mineral Resources of Nepal, Book, DMG, $154 \mathrm{p}$

DMG, 2008, Department of mines and Geology, Web site, Introduction http:/ www.dmgnepal.gov.np/intro.html

Jha, U., 1978. Investigation Reports of Udaipur (Sindali) Limestone Deposit, Unpublished report of Department of Mines and Geology (DMG).

JICA, 1978. Udayapur Cement Plant Establishment Project Feasibility Study Report, Unpublished report of Japan International Cooperation Agency, V. 1 (main part).

Kayastha, N.B., 1977. Regional geology of Udayapur and Diktel area, Unpublished report of DMG.

Khatri, D. B., 1978, Investigation of Udaipur (Sindali) Limestone Deposit, Unpublished report of DMG.

Kreiter, V. M., 1966, geological Prospecting and Exploration, Mir Publisher, Moscow, 309p.

Lea, F. M., and Desch, C.H., 1968, the Chemistry of Cement and Concrete, Edward Arnold \& Co., London

Pandey, P.R., 2003, Geochemical Analysis and Reserve Estimation of Sindali IImestone Deposit, Sukaura, Udayapur, Eastern Nepal, Unpublished M. Sc. Dissertation submitted to the Central Department of Geology, Tribhuvan University, 72p.

Shrestha, J.N., 2001, Prospects and exploration opportunities of cement grade limestone in Nepal, HMG Nepal, Ministry of Industry, Commerce and Supplies, DMG, Brochure of Unpublished Report 